\begin{tabular}{|l|l|l||}
\hline \multicolumn{2}{|c|}{ PublisherInfo } \\
\hline \hline PublisherName & $:$ & BioMed Central \\
\hline \hline PublisherLocation & $:$ & London \\
\hline \hline PublisherImprintName & $:$ & BioMed Central \\
\hline \hline
\end{tabular}

\title{
Arrays for replication
}

\begin{tabular}{|l|l|l||}
\hline \multicolumn{2}{|c|}{ ArticleInfo } \\
\hline \hline ArticleID & $:$ & 3749 \\
\hline \hline ArticleDOI & $:$ & $10.1186 /$ gb-spotlight-20000821-02 \\
\hline \hline ArticleCitationID & $:$ & spotlight-20000821-02 \\
\hline \hline ArticleSequenceNumber & $:$ & 186 \\
\hline \hline ArticleCategory & $:$ & Research news \\
\hline \hline ArticleFirstPage & $:$ & 1 \\
\hline \hline ArticleLastPage & $:$ & 2 \\
\hline \hline & & RegistrationDate : 2000-08-21 \\
ArticleHistory & $:$ & OnlineDate $\quad$ 2000-08-21 \\
\hline \hline ArticleCopyright & $:$ & BioMed Central Ltd2000 \\
\hline \hline ArticleGrants & $:$ & \\
\hline \hline ArticleContext & $:$ & 130591111 \\
\hline \hline
\end{tabular}




\section{William Wells}

Email: wells@biotext.com

DNA microarrays are normally used to detect variation in mRNA abundance. But in the August 15 Proceedings of the National Academy of Sciences Khodursky et al. use the arrays to track the progress of replication forks in Escherichia coli (Proc Natl Acad Sci USA 2000, 97:9419-9424). In a bacterial culture that is replicating synchronously, genomic DNA from replicated regions gives a stronger array signal than unreplicated DNA. Khodursky et al. use this signal variation to show that normal replication forks progress at $45 \mathrm{~kb} / \mathrm{min}$, whereas those in bacteria lacking functional gyrase slow to $14 \mathrm{~kb} / \mathrm{min}$, and eventually stop. The residual activity seems to be provided by topoisomerase IV (topo IV). When both gyrase and topo IV are inhibited, replication forks halt almost immediately. In the past, the importance of topo IV in replication has been masked by non-specific gyrase inhibitors. The speed of the halt in replication also suggests that torsional stress from replication is distributed not throughout the chromosome but in a smaller, topologically closed domain.

\section{References}

1. Quantitative monitoring of gene expression patterns with a complementary DNA microarray.

2. Proceedings of the National Academy of Sciences, [http://www.pnas.org/] 